\title{
ANALISIS TEOLOGIS GEREJA YANG REFORMATORIS SERTA IMPLIKASINYA BAGI KEKRISTENAN MASA KINI
}

\author{
Yornan Masinambow \\ Institut Agama Kristen Negeri Manado \\ J. Bougenville Tateli Satu, Kecamatan Mandolang, Kabupaten Minahasa, Sulawesi Utara 95661 \\ Email: yornanmasinambow@yahoo.com
}

\begin{abstract}
ABSTRAK: Berdasarkan pemikiran bahwa Kekristenan sekarang ini berada di zaman yang tidak memutlakkan satu otoritas, termasuk Firman Tuhan, gereja dapat dipengaruhi oleh sekularisasi dan tidak lagi mewartakan injil Yesus Kristus yang murni. Maka artikel ini akan mendeskripsikan serta merumuskan gagasan teologis biblis tentang gereja berdasarkan pemikiran para reformator, yakni Luther, Calvin dan Zwingli. Hasil dari pendekatan literatur teologis dapat disingkapkan bahwa gereja reformatoris menaruh perhatian pada beberapa aspek penting yang membuat gereja mampu memengaruhi dunia dalam setiap aspek kehidupan, yaitu gereja yang memberitakan Injil, mengajar dan berkhotbah, mengorganisir serta memimpin, melaksanakan sakramen, dan menerapkan disiplin gereja. aspek-aspek tersebut bukanlah demi gereja itu sendiri yang di dalamnya terdapat orang-orang pilihan Allah, melainkan demi memuliakan Allah Tritunggal.
\end{abstract}

Kata Kunci: teologi, reformator, gereja reformatoris, kekristenan masa kini.

\section{THEOLOGICAL ANALYSIS OF THE REFORMATORY CHURCH AND ITS IMPLICATIONS FOR CURRENT CHRISTIANITY}

\begin{abstract}
Based on the thought that Christianity today is in an age that does not absolutize one particular authority, including the Word of God, the church can be influenced by secularization and no longer preach the pure Gospel of Christ. Therefore, this article is going to describe and formulate the biblical-theological ideas regarding the church based on the thought of the reformers, namely Luther, Calvin, and Zwingli. The result of the theological-literary approach is that the reformatory church pays attention to a couple of essential aspects that make the church be able to influence the world in every aspect of life, namely the church that preaches the gospel, teaches and preaches, organizes and leads, conducts the sacrament, and implements church discipline. These aspects are not for the sake of the church itself, but for the sake of glorifying God.
\end{abstract}

Keywords: theology, reformers, reformatory church, current christianity.

\section{PENDAHULUAN}

Dewasa ini arus modernisme atau postmodernisme secara sadar maupun tidak sadar masuk ke dalam setiap pemikiran kehidupan manusia yang eksistensial baik secara personal maupun komunal. Kemajuan zaman dari waktu ke waktu berdasarkan pemikiran atau mentalitas di atas dapat menggeser konsep spiritualitas aga- ma termasuk di dalamnya adalah Kekristenan. Dengan bebasnya pemikiran manusia menentukan segala aspek kehidupan dan tidak mau lagi tunduk dalam suatu otoritas, memunculkan kebebasan untuk melakukan segala hal yang menurut penilaiannya baik. Jikalau demikian, maka gereja yang ada di tengah-tengah masyarakat masa kini dapat dinilai apakah mampu 
menjawab segala kebutuhan, keinginan manusia yang menuntut kebebasan. Kita bisa melihat apakah gereja dapat terbawa arus zaman atau tetap melawan zaman melalui pemberitaan Injil Yesus Kristus yang bertujuan untuk bisa mentransformasikan dunia di segala aspek, baik sosial, budaya, pendidikan, politik dan ekonomi (Stevanus, 2018, p.287). Penting sekali bagi gereja secara jelas mengenal jati dirinya dan tujuannya ke depan. Oleh karena itu, gereja juga perlu mengenal kehendak Tuhan dan inti permasalahan gereja yang ada.

Gereja bisa cenderung meleburkan diri dengan kebutuhan zaman dan berasimilasi dengan nilai dan cara hidup yang sekuler. Contohnya saja sejumlah pemimpin gereja menyadari bahwa pola pelayanan dan cara kehidupan gereja sudah tidak lagi mendukung pertumbuhan kerohanian anggota jemaat, dan sebagai jalan keluarnya, mereka mengadopsi berbagai cara praktik sekuler ke dalam kehidupan gereja, misalnya melakukan seminar-seminar motivasi diri, dengan pendekatan humanistik psikologis. Ketika gereja menganggap hal tersebut sangat penting bagi kehidupannya, maka gereja mulai kehilangan jati dirinya sebagai tubuh Kristus. (Wijaya Lo, 2018, p.1). Di sisi lain, tidak bisa dipungkiri bahwa efektifitas kemajuan teknologi juga menolong untuk mempermudah kehidupan sehari-hari, termasuk pelayanan.

Dalam menghadapi perkembagan zaman saat ini, gereja perlu untuk mempertimbangkan kembali berbagai catatan historis teologis sebagai perenungan. Oleh karena itu, gereja perlu untuk memikirkan serta merefleksikan karya teologis mereka, agar bisa menghadirkan makna religius yang mendalam berkaitan dengan usaha gereja untuk mewartakan Injil Kristus di setiap karya pelayanan. Namun sebaliknya, gereja sekarang ini lebih mengutamakan kemauan serta kepuasan manusia sebagai hal yang utama dalam setiap perumusan konsep pelayanan dalam kehidupan bergereja. Sementara hal-hal yang mendasar dalam aspek teologis biblis gereja justru tidak lagi menjadi concern utama, yang kemudian ditinggalkan serta tidak lagi dipandang berharga untuk dipertahankan. Cara seperti ini harus segera disikapi dengan serius.

Tulisan ini akan membahas konsep gereja yang reformatoris dengan alasan bahwa gereja yang reformatoris hendak mengembalikan lagi Kekristenan kepada otoritas Alkitab melalui anugerah Allah dan juga iman kepercayaan yang sesuai dengan wahyu Allah. Dengan begitu kita akan memahami apa sebenarnya yang menjadi makna atau esensi gereja yang reformatoris. Hal ini akan terkait dengan pewartaaan kebenaran serta semangat mewartakan Injil.

\section{METODE}

Metode penelitian yang dipakai adalah pendekatan kualitatif. Menurut Moleong, "Penelitan kualitatif adalah penelitian yang menghasilkan berbagai data deksriptif berupa kata-kata tertulis" (Moleong, 2002, p. 9). Penelitian kualitatif adalah penelitian yang dilakukan dengan terencana serta sistematis. Penelitian kualitatif dilakukan dengan serasi serta harus mendukung satu dengan yang lain supaya penelitian tersebut mempunyai kualitas yang memadai serta hasil yang tidak diragukan (Fathoni, 2006, p.104). Dalam penelitian kualitatif ini, penulis menggunakan pendekatan studi literatur. Metode studi literatur atau kajian pustaka adalah metode pengumpulan data melalui berbagai buku atau dokumen yang merupakan hasil penelitian sebelumnya, yang yang dapat dijadikan acuan terkait dengan ide atau gagasan penelitian artikel ini (Moleong, 2005, p. 217).

Untuk memperoleh pemahaman secara teoretik yang konseptual mengenai substansi gereja yang reformatoris, maka penulis melakukan studi literatur atau kepustakaan. Penulis mempelajari konsep atau gagasan secara historis teologis khususnya ide-ide atau pemikiran para reformator gereja se- 
cara teologis, terkait dengan ciri gereja yang reformatoris melalui bahan-bahan literatur yang ada. Adapun tahapan-tahapan dalam menyelesaikan tulisan ini adalah penulis melakukan kajian literatur dari berbagai macam buku, jurnal, dengan gambaran yang jelas serta sistematis, tentang analisis teologis gereja yang reformatoris yang kemudian diaplikasikan pada Kekristenan masa kini. Selanjutnya, penulis melakukan penyimpulan secara teoritis dalam rangka melakukan refleksi teologis terkait relevansi hasil penelitian dan kehidupan bergereja pada masa kini.

\section{HASIL DAN PEMBAHASAN}

\section{Gereja}

Istilah ekklesia dipergunakan oleh Tuhan Yesus Kristus ketika la membicarakan tentang pembangunan sidang, jemaat atau gereja-Nya di atas "batu karang" ini dan juga dalam hubungan dengan disiplin gereja (Mat. 18:17). Gereja hadir sebab Tuhan Yesuslah yang menebus dan memanggil kaum pilihan Allah untuk menjadi pengiringNya, serta dipanggil dalam suatu persekutuan (koinonia) dengan Dia. Dapat juga dikatakan bahwa gereja dalam persekutuannya terkait erat dengan Kristus. Bila dalam gereja tidak ditemukan suatu persekutuan yang indah dengan Kristus, maka gereja tersebut tidak bisa dan tidak layak dikatakan sebagai gereja. Pada waktu Yesus Kristus memanggil dua belas muridNya, mereka terkumpul untuk menjadi satu kesatuan yang nantinya terikat pada penebusan Kristus (Mawikere, 2019, p. 1).

Secara istilah, kata "gereja" berasal dari bahasa Portugis "igreja", yang berkaitan dengan bahasa Spanyol "iglesia", bahasa Perancis "eglise", serta bahasa Latin "ecclesia", yang berasal dari kata Yunani "kyriake" yang berarti "dimiliki oleh Tuhan" (Heuken, 1992, p. 381). Dalam Perjanjian Baru kata "gereja" diterjemahkan atau diartikan menjadi kata "jemaat", atau "sidang" serta "sidang-jemaat". Istilah Yunani mema- kai kata "ekklesia" yang pada awalnya diterjemahkan dengan kalimat "dipanggil berhimpun untuk menghadiri rapat rakyat." Istilah lain yang bisa menjadi perumusan kata "gereja" adalah "dipanggil" oleh Allah atau "berhimpun" bersama Allah (Niftrik \& Boland, 1990, p. 359). Kata "ek" dalam "ekklesia" atau "ekkaleo" sering diinterpretasikan sebagai kalimat "ke luar dari sekumpulan orang-orang" dan terkait korelasinya dengan Alkitab untuk kata "ekklesia" itu sendiri, kata ini diartikan bahwa "Gereja terdiri dari orang-orang pilihan Allah yang dipanggil keluar" (Berkhof, 2017, p. 7). Selain itu, gereja merupakan suatu hubungan intim yang sifatnya religius yang ditempatkan oleh Allah sendiri di dunia untuk melakukan pelayanan rohani terhadap manusia dengan tujuan untuk memuliakan Allah.

Wayne Grudem mendefinisikan gereja sebagai berikut.

The church is the community of all true believers for all time. The term "the church" is used to apply to all those whom Christ died to redeem, all those who are saved by the death of Christ. But that must include all true believers for all time, both believers in the New Testament age and believers in the Old Testament age as well (Grudem, 1994, p.744).

Istilah "kyriake" merupakan kata untuk persekutuan setiap orang percaya yang telah dipanggil menjadi milik Tuhan. Kata ini telah digunakan pada zaman setelah para rasul, dalam hal ini bagi gereja mula-mula sebagai sebuah institusi awal. Kata ini memberikan penekanan bahwa gereja adalah milik Allah (Hadiwijono, 2016, p. 362). Siburian menyatakan bahwa gereja adalah organisme sebagai suatu "kuriakon". Lebih lanjut dikatakan bahwa gereja adalah "milik Tuhan" yang bukan sebatas pada bangunan serta institusi yang berdasarkan aturan semata (Siburian, 2018, p. 19). 


\section{Gereja Dalam Perspektif Alkitab}

\section{Perjanjian Lama}

Dalam Perjanjian Lama, istilah yang dipakai terkait gereja yaitu "qahal" atau "kahal" berasal dari akar kata "qal" diterjemahkan dengan kata "memanggil", serta kata "edhah" dari kata "ya'adh" artinya "memilih" juga bisa diartikan dengan kata "menunjuk", serta ditafsirkan dengan istilah "bertemu bersama-sama di satu tempat yang telah ditunjuk." Hal tersebut menunjuk pada bangsa Israel sebagai umat pilihan Allah. Jadi, sering juga dijumpai kedua kata itu bersama menjadi "qehal'edhah" yang artinya "kumpulan jemaah" (Kel. 12:6; Bil. 14:5; dan Yer. 26:17). Kata "edhah" sendiri merupakan kata yang digunakan dalam kitab-kitab Pentateukh (Keluaran, Imamat, Bilangan) serta dapat dijumpai dalam kitab Yosua. Kata "qahal" juga banyak dijumpai dalam kitab Tawarikh, Ezra dan juga Nehemia. Kata "qahal" juga dapat diartikan sebagai suatu bangsa yang terikat oleh berbagai hukum-hukum Tuhan. Dan bangsa tersebut kemudian dinaungi serta dipimpin oleh Tuhan serta masuk dalam suatu covenant bersama Tuhan berdasarkan inisiatif Dia sendiri. Melalui penjelasan tersebut dapat diartikan adanya perjumpaan atau pertemuan bersama suatu umat. Dalam Kitab Pentateukh juga kata "qahal" kemudian diterjemahkan dengan kata "synagogue". Kata ini adalah terjemahan yang paling umum dipakai dalam Septuaginta untuk "'edhah", dan juga untuk menerjemahkan kata qahal yang dipakai di dalam lima Kitab Musa (Berkhof, 2017, p. 5). Gereja Tuhan atau Qahal dalam Perjanjian Lama berarti Allah sendiri yang mempersatukannya. Maksudnya untuk menghormati serta mengabdi kepada Allah, bukan pada tujuan untuk melayani manusia (Kej.1:23). Kemudian, Allah memberikan Firman-Nya serta sikap atau respon oleh umat Israel adalah percaya (Soedarmo, 2011, p. 219).

\section{Perjanjian Baru}

Istilah gereja atau church dalam ba- hasa Inggris diterjemahkan dari istilah Yunani yaitu "ekklesia", yang berasal dari kata "ek", berarti "keluar dari", dan "kaleo" yang berarti "memanggil'. Jadi gereja dapat dikatakan sebagai orang-orang yang dipanggil keluar. Selain itu, dapat pula diartikan bahwa kata "ekklesia" digunakan dalam pengertian teknis yang ditujukan terhadap gereja di zaman perjanjian baru, yaitu sekumpulan orang-orang percaya yang telah dipanggil dalam Kristus Yesus (Enns, 2016, p. 393). Dapat dikatakan juga bahwa 'dipanggil keluar' berarti mereka tidak lagi di bawah perhambaan. Mereka telah bebas, serta tidak menjadi pelayan yang setiap saat harus menghadiri pertemuan. Gereja merupakan orang-orang yang telah dipanggil untuk berkumpul bersama serta berelasi dalam suatu komunitas kaum pilihan Allah untuk memuliakan Kristus (Niftrik \& Boland, 2016, p. 359). Yesus pertama kali menyebutkan istilah ekklesia dalam Kitab Injil. la kemudian menggunakan istilah tersebut untuk menunjuk kepada para murid-Nya yang bersama-sama dengan Dia (Mat. 16:18). Kemudian, para murid mengenal Dia sebagai Tuhan (kurios) (Berkhof, 2017, p. 7). Dalam Perjanjian Baru gereja diibaratkan sebagai Tubuh Kristus (1 Kor. 12), yakni suatu kiasan yang menyatakan bahwa setiap orang percaya bukan pertama-tama berada di dalam gereja sebagai lembaga, tetapi setiap umat Tuhan baik secara personal maupun bersama-sama (Abineno, 2018, p.192).

Istilah ini tidak hanya digunakan untuk menunjuk pada arti gereja secara universal saja, seperti dalam Efesus 1:23; Kolose $1: 18$, tetapi juga untuk menunjuk pada suatu kumpulan jemaat yang tunggal (1 Kor. 12:27). Istilah tersebut berfokus pada adanya suatu kesatuan gereja, baik secara lokal dan universal serta sifat kesatuannya yang teratur dan adanya relasi dengan Kristus sebagai Kepala Gereja. Selain itu, ada istilah "Bait Allah", disebut di gereja Korintus yang di mana Roh Kudus tinggal (1 Kor. 3:16). Dijelaskan juga dalam surat 
Efesus 2:21-22, di mana Paulus menjelaskan mengenai orang yang percaya harus terus bertumbuh menjadi "satu Bait Tuhan yang kudus". Setiap pernyataan tentang gereja akan menjadi pernyataan tentang Kristus. Adanya suatu penjelasan mengenai Kristus, secara langsung juga menjadi penjelasan mengenai gereja. Setiap pemaparan mengenai Kristus selalu tertuju kepada gereja dengan masa depan yang bersifat universal, kerajaan yang mesianis. Kristus yang adalah Mesias merupakan landasan penting bagi gereja sebagai sebuah pengharapan yang terus akan digenapi. Dengan demikian, gereja-Nya harus menjadi "persekutuan mesianis" yang berorientasi dalam misi menuju kerajaan Allah yang sedang datang (Bauckham, 1996, p. 142).

\section{Gereja Perspektif para Reformator}

\section{Martin Luther}

Gereja yang reformatoris dimulai dengan Martin Luther. Luther memandang tentang gereja serta penyusunannya langsung berhubungan dengan ajarannya tentang pembenaran (yustifikasi) hanya oleh iman. Sejarah gereja mencatat bahwa pada tanggal 31 Oktober 1517 Luther menempelkan kertas dengan 95 dalil di pintu gedung gereja Wittenberg. Ini dikarenakan, gereja yang pada waktu itu adalah gereja Roma Katolik memakai otoritas gerejawinya untuk mendapatkan lebih banyak harta, kekuasaan, serta membela kaum bangsawan. Gereja Roma Katolik kemudian mengadakan surat jual-beli keselamatan yang dikenal dengan istilah indulgensia demi untuk mendapatkan dana yang banyak (Abineno, 2015, p. 58).

Dalam dalil-dalil itu Luther berusaha untuk mengajar orang-orang percaya untuk berpikir secara benar tentang pertobatan yang sejati dan hukuman. Gereja bagi Luther adalah kumpulan setiap orang percaya yang dibenarkan. Luther memberikan suatu hal utama dan tetap bagi gereja yang reformatoris yaitu pemberitaan atau pewartaan firman tentang anugerah Allah.
Baginya, kabar mengenai Firman Allah atau Injil adalah sesuatu yang sangat penting berkaitan dengan identitas gereja itu sendiri, dikarenakan jikalau firman tersebut diberitakan, maka di sana terdapat iman orang percaya sebagai suatu tanggapan atas anugerah. Di mana iman itu ada pasti di sana terdapat pemberitaan Firman Allah yang murni dan tidak boleh ada komunitas manusia yang dapat mengklaim menjadi "gereja Tuhan" itu sendiri kecuali persekutuan gereja tersebut dilandaskan di atas Injil Kristus (McGrath, 2018, pp. 248-249).

\section{Ulrich Zwingli}

Pandangan gereja menurut Zwingli agak berbeda dengan pandangan Martin Luther. Pandangannya lebih mirip dengan pandangan Bucer dan juga Calvin. Jikalau Luther menyatakan bahwa gereja sebagai kerajaan Kristus adalah gereja yang seluruhnya batiniah. Zwingli sebaliknya berpendapat bahwa kerajaan Kristus Yesus bukan hanya batiniah tetapi juga lahiriah. Zwingli sangat erat menghubungkan gereja dan negara. Menurutnya, Setiap orang Kristen tidak lain merupakan warga sipil yang baik serta setia dan juga kota yang bercorak Kristen juga dapat mencerminkan gereja Kristen yang baik. Selanjutnya, Zwingli berpendapat bahwa setiap gereja Kristen dan pemerintah sangat dibutuhkan serta diperlukan, dan juga pemerintah yang menjalankan jabatan yang profetis juga sangat penting. (Abineno, 2015, p.65). Zwingli juga memberi penekanan pada hal-hal penting yang diatur oleh pemerintah dan gereja, yang pada zaman Zwingli yang juga relevan dewasa ini yaitu: disiplin dan penerapannya yang menurut Zwingli adalah tugas gereja. "Ekskomunikasi" (pengucilan) adalah hak gereja. Usul Zwingli, yang ia ajukan pada tahun 1525 tentang hal itu kepada pemerintah, tidak mau dibicarakan oleh Dewan Kota (Abineno, 2015, p. 67).

\section{John Calvin}

Calvin memikirkan bahwa kesetiaan kepada Kitab Suci dan kasih Kristus ter- 
hadap gereja-Nya adalah suatu fondasi kuat, kaya bagi gereja karena Kristus sendiri yang memimpin karena Dialah kepalanya yang telah meneladankan hidup yang taat kepada kehendak Allah Bapa-Nya sekalipun untuk itu la mengalami penderitaan. Calvin memandang bahwa, gereja yang sehat adalah gereja yang biblikal. Di dalamnya pasti dengan setia terus memberitakan Firman Allah yang murni kepada umat-Nya, yang berdampak pada pembentukan serta penguatan otot-otot gereja itu sendiri dalam kesatuan dan kesetiaan. la selalu merujuk dan menekankan pada pemberitaan Firman Tuhan yang murni sebagai sarana utama untuk merealisasikan kehormatan Allah dan kesejahteraan gereja (Hall \& Lillback, 2009, p. 449).

Dalam Institutio, dijelaskan bahwa jikalau kita mengaku dalam pengakuan iman rasuli percaya kepada gereja, maka yang dimaksudkan bukan hanya gereja yang kelihatan, yang kita bicarakan sekarang, tetapi juga semua orang pilihan Allah. Gereja itu dinamakan "Katolik" atau "Am", serta bersifat kudus sebab tidak mungkin didapati ada dua atau tiga gereja tanpa membuat Kristus itu sendiri terbagi yang berarti sangat mustahil. Adalah sangat penting bagi umat Tuhan bahwa kita percaya gereja, yang menjadi anggota di dalamnya berdampak pada manusia bertumpu atau bersandar pada fondasi yang kokoh sehingga tidak mungkin jatuh dan roboh, sekalipun seluruh bangunan dunia tergoyahkan (Calvin, 2015, p. 226).

\section{Prinsip-Prinsip Gereja yang Reformatoris}

Para reformator membangun teologi mereka di atas karya gereja abad-abad permulaan. Teologi gereja yang reformatoris selalu membangun karya-karya masa lampau dengan pernyataan-pernyataan iman yang komprehensif yang bertanggung jawab di hadapan Tuhan, seperti Pengakuan Iman Rasuli, Nicea, Rumusan Chalcedon. Semua pemikiran reformator adalah untuk semua orang sepanjang zaman. Gereja yang reformatoris melalui para refomator merevisi atau mengoreksi misalnya tentang pemahaman atau pengertian gereja dan sakramen (Lumintang, 2009, p. 265).

Gereja harus selalu memberikan melayani dengan tujuan-tujuan biblikal yang tinggi demi kemuliaan Allah Tritunggal serta untuk kesejahteraan umat-Nya. Gereja menjadi sarana yang diberikan oleh Allah untuk memastikan setiap pengkhotbahpengkhotbah diperlengkapi dengan karunia Tuhan, dan tetap setia serta menjaga mereka untuk kelanjutan gereja itu sendiri (Hall \& Lillback, 2009, p.452).

Selain itu, berbicara tentang gereja yang reformatoris berarti berbicara tentang gereja sebagai "Ibu" yang manfaatnya sangat besar bagi orang percaya. Hakikat gereja yakni sebagai "lbu" bagi semua orang percaya (the church is our mother). Jadi gereja sebagai keluarga yang berperan memberikan edukasi teologis bagi anakanaknya (seluruh warga) ke arah kehidupan yang sesuai dengan kehendak kepala gereja yakni Kristus (Niesel, 2006, p.186). Baik Luther maupun Calvin menyatakan bahwa gereja yang benar merupakan persekutuan orang percaya dan disucikan di dalam Kristus dan disatukan dengan Dia sebagai Kepala mereka. Belgic Confession menyebutkan, "Kami percaya dan mengakui satu gereja yang universal, yang merupakan jemaat yang kudus dari orang percaya yang benar, yang mengharapkan keselamatan mereka dalam Yesus Kristus, yang dicuci oleh darah-Nya, disucikan dan dimeteraikan oleh Roh Kudus." Sedangkan dalam Westminster Confession memberikan definisi esensi gereja, "Gereja yang am atau universal, yang tidak nampak, terdiri dari keseluruhan orang pilihan yang telah dan akan dikumpulkan menjadi satu, di bawah Kristus sebagai Kepala, dan Gereja adalah mempelai wanita, tubuh, kepenuhan dari diri-Nya yang memenuhi semua di dalam semua" (van den End, 2019, p. 130).

Di dalam gereja yang reformatoris, Kristus sungguh-sungguh mau menguasai 
segenap hidup umat-Nya. Siapa yang mengakui nama-Nya, haruslah menjauhkan diri dari segala dosa dan kedurhakaan. Gereja yang benar dapat dikenal dengan pemberitaan firman menurut Kitab Suci dan pelayanan sakramen, sesuai dengan kehendak Kristus. Gereja harus mencerminkan pemerintahan Tuhannya (Berkhof \& Enklaar, 2016, p. 176). Yesus Kristus harus menjadi dasar gereja, Firman Allah harus menjadi tolak ukur iman dan kegiatan gereja, serta Roh Allah harus menjadi pelaksana. Hanya mereka yang secara terang-terangan mengakui bahwa Yesus adalah Kristus berhak menjadi anggota gereja (Thiessen, 2015, p. 486).

Gereja yang reformatoris setidaknya harus memiliki lima prinsip yang bersifat teologis biblis yakni:

\section{Gereja yang Memberitakan Injil}

Injil memiliki dua sisi berita yakni murka dan penghakiman Tuhan atas orangorang berdosa, dan kedua, anugerah serta pengampunan Tuhan bagi mereka yang percaya. Memberitakan Injil berarti mengumpulkan semua orang-orang pilihan, lalu kemudian diajar, dipimpin, dilayankan sakramen, didispilin, dan diajak untuk aktif memberikan suatu pengaruh positif bagi masyarakat dan negara. Gereja yang tidak memberitakan Injil adalah gereja yang tidak sehat dan mungkin hanya menunggu waktu untuk mati (Matalu, 2017, p. 810).

Stephen Tong membagi sifat-sifat dasar Injil yang tentunya harus dimiliki oleh gereja-gereja reformatoris yang harus dan siap sedia untuk terus memberitakan Injil yaitu sebagai berikut (Tong, 1988, p. 20).

Sifat Universal. Sifat ini mencakup keselamatan Kristus yang berasal dari kekekalan maka kuasa keselamatan-Nya melampaui batas-batas geografi. Dikatakan: "Injil Kerajaan ini akan diberitakan di seluruh dunia menjadi kesaksian bagi semua bangsa, sesudah itu barulah tiba kesudahannya" (Mat. 24:14), serta "Jadikanlah semua bangsa murid-Ku” (Mat. 28:19). Ucapan atau perkataan tersebut mematahkan persepsi orang Yahudi yang sempit, serta mampu menyatakan sifat universal dari Injil.

Injil Kristus Yesus sanggup untuk mentransformasi masyarakat dari berbagai macam aspek. Kerygma mengenai Kabar Baik tersebut harus dengan sikap yang mengasihi setiap orang. Gereja harus terus memberitakan Injil tanpa memandang bulu (Tong, 1988, p. 32). Memahami akan sifat dasar Injil yang universal, akan mengarahkan diri kita untuk memiliki jiwa Injili yang juga universal.

Dapat dikatakan juga bahwa keabsahan Amanat Agung yang masih relevan untuk gereja, menegaskan mengenai jangkauan pemberitaan Injil adalah untuk seluruh dunia, untuk semua orang (Verkuyl, 1978, p. 20). Selain itu secara historikal, gereja yang Calvinist merumuskan dalam Synod of Dort (the Canons of Dort) point satu, artikel 3: "Pemberitaan Injil", point empat nomor 8: "Panggilan Injil yang serius," artikel 10: "pertobatan sebagai karya Allah," artikel 17: "Allah menggunakan dalam karya regenerasi," dan sebagainya. Pada intinya point-point dalam "The Canons of Dort" berbicara mengenai tugas gereja adalah untuk memberitakan Injil kepada semua orang dengan serius, bukan hanya kepada orang yang dipilih (tidak diketahui) tapi untuk semua orang, dan Tuhan memakai alat-alat-Nya, yaitu rasul-rasul untuk mengajar (The Canon of Dorts, 2019).

Sifat paradoks. Maksud dari Injil yang bersifat paradoks ini adalah pada saat diberitakan, setiap orang yang memerlukan Injil merasa diri tidak perlu Injiil, tetapi setiap manusia yang tidak sadar mengenai perlunya Injil adalah mereka yang paling memerlukan Injil. Jika gereja mengenal dengan baik tentang sifat paradoks terhadap injil, maka gereja tidak akan putus asa, akan selalu giat, tekun, serta memiliki semangat juang yang teguh dalam memberitakan Injil.

Sifat inisiatif. Gereja yang giat memberitakan injil harus "pergi" dengan inisiatif. 
Setiap orang percaya dalam gereja harus terus saling mengingatkan, menegaskan, dan mempertahankan konsep "pergi" ini. Orang yang memiliki kerinduan untuk mengabarkan Injil, pasti mengerti kehendak Tuhan karena mereka sadar bahwa Allah telah berinisiatif lebih dahulu terkait keselamatan setiap orang percaya. Mereka yang mengabarkan injil selalu melakukannya berdasarkan prinsip-prinsip yang dinyatakan dalam Alkitab. Gereja yang memiliki inisiatif untuk pergi mengabarkan Injil dengan semangat berapi-api adalah gereja yang memiliki sifat inisiatif untuk terus memberitakan kabar baik tentang Kristus.

Sifat Melahirkan Kembali. Setiap orang yang memberitakan kabar keselamatan mengenai Injil Yesus Kritus pasti menghasilkan komunitas orang percaya yang telah diselamatkan dan lahir baru, serta mereka yang dilahirkan kembali pasti memiliki hati yang telah terdorong untuk terus mengabarkan injil kepada orang lain untuk segera bertobat. Injil tidak akan pernah padam hanya karena adanya penganiayaan. Namun, justru sebaliknya, semakin dianiya atau dihalangi Injil justru semakin bertumbuh.

\section{Gereja yang Mengajar dan Berkhotbah}

Gereja yang memberikan pengajaran dan khotbah merupakan hal yang paling utama untuk membangun tubuh Kristus, yakni agar mereka mendengar setiap Firman yang diberitakan, kemudian memahaminya, memikirkannya, merenunginya lalu menerapkannya dalam kehidupan mereka sehari-hari sebagai orang-orang percaya yang takluk kepada pemikiran Kristus (Matalu, 816, p. 816).

Pemberitaan Firman Tuhan ditujukan kepada dunia, yaitu dunia bangsa-bangsa. la berlangsung di dalam dunia dan ia adalah suatu perjuangan untuk keselamatan dunia. Dalam perspektif kerugmatis ini sebagai suatu pemberitaan yang mengaktualisasikan Injil Kerajaan Allah, sampai ke ujung bumi ia tetap terpelihara dalam karakternya sebagai pemberitaan Firman (Abineno, 2018, p. 216).

Menjadi realita bahwa ada begitu banyak yang tidak mempedulikan atau memberi perhatian besar pada pemberitaan Firman Tuhan yang benar, kuat, disiplin dan ketat dari atas mimbar. Dan juga tidak menaruh perhatian penting pada pelajaran pemahaman Alkitab dan pembelajaran doktrinal. Gereja yang memberikan pengajaran adalah sama dengan gereja yang memberikan suatu landasan pengetahuan bagi setiap orang percaya, berlandaskan Firman Tuhan di bawah naungan Roh Kudus melalui berbagai macam pembelajaran atau pendidikan yang dilakukan oleh gereja, sehingga dalam diri orang percaya akan terbentuk suatu pemahaman rohani yang baik serta teguh berdiri di hadapan Allah Trinitas dalam praksis kasih terhadap sesamanya (Boehlke, 2011, p. 413). Tugas utama gereja bukan saja memanggil orangorang yang berdosa kepada Kristus, tetapi juga untuk mendidik orang Kristen, menguatkan iman mereka, membawa mereka terus maju dalam jalan pengudusan, dan memberikan suatu landasan kokoh bagi Bait Allah.

Paulus menjelaskan tentang hal ini ketika ia mengatakan bahwa Kristus memberikan jabatan mengajar bagi gereja "untuk memperlengkapi orang-orang kudus bagi pekerjaan pelayanan, bagi pembangunan tubuh Kristus, sampai kita semua telah mencapai kesatuan iman dan pengetahuan yang benar tentang Anak Allah, kedewasaan penuh dan tingkat pertumbuhan yang sesuai dengan kepenuhan Kristus." (Ef. 4:12,13). Gereja yang reformatoris sangat menekankan pengajaran pokok-pokok iman Kristen yang disusun sedemikian rupa agar sesuai untuk pertumbuhan diri secara utuh, baik aspek spiritual, emosional, intelektual dan juga psikomotorik.

Pemberitaan Firman dalam istilah lain juga disebut "khotbah", yang berlangsung tiap-tiap minggu dalam ibadah Jemaat. Bagi 
banyak gereja reformatoris atau Protestan, khotbah merupakan unsur yang paling penting dari ibadah Jemaat. Ibadah jemaat dianggap gagal, kalau diselenggarakan tanpa khotbah. Khotbah bergerak antara dua kutub yakni eksplikasi dan aplikasi. Yang dimaksud dengan eksplikasi adalah tafsiran nas Alkitab; tafsiran-tafsiran tentang perbuatan-perbuatan dan perkataan dari sejarah perjanjian dalam konteks perbuatanperbuatan dan perkataan-perkataan itu dalam Kitab Suci. Kemudian aplikasi adalah penerapan; yakni penerapan dari nas yang ditafsirkan itu ke dalam hidup yang konkrit (konteks) dari anggota-anggota jemaat. Antara eksplikasi dan aplikasi memiliki hubungan erat. Dalam eksplikasi yang benar telah terkandung aplikasi dan dalam aplikasi yang benar turut terdengar eksplikasi.

Dapat dikatakan juga bahwa pemberitaan firman adalah sebagai proklamasi tentang keselamatan Allah yang bertolak dari suatu nas alkitabiah. Nas itu ditafsirkan dan diterapkan dalam hidup jemaat yang konkrit. Pengajaran yang kuat harus diperkuat dengan khotbah yang bermutu. Posisi khotbah menjadi menonjol, karena para reformis menegaskan sikap hormat mereka kepada Alkitab (Sola Scriptura). Khotbah dapat diberitakan dengan tujuan untuk mengedukasi, karena khotbah merupakan sarana yang efektif untuk dapat mendidik setiap umat Tuhan (Sutanto, 2012, p. 38-39).

Khotbah dapat dijadikan sarana untuk membangun iman warga jemaat. Khotbah yang diberitakan baik secara ekspositori maupun tematik, sistematik dan seimbang sangat berguna dan bisa membangun iman umat Tuhan. Melalui khotbah juga gereja dapat melakukan pembelaan diri yang menjernihkan dari berbagai macam kesalahpahaman, meneduhkan situasi, dan mengajak pihak yang tidak bersahabat melihat keadaan yang sesungguhnya. Selain itu, melalui khotbah gereja dapat menjangkau mereka yang belum percaya kepada Tuhan Yesus Kristus.

\section{Gereja yang Mengorganisir dan Memimpin}

Mengatur dan memimpin jemaat, serta melaksanakan administrasi gereja dengan baik dan benar juga sangat penting. Bentuk administrasi gereja berupa kerjasama dalam hal mencatat berbagai macam kegiatan pelayanan gereja, menggunakan segenap fasilitas dengan maksimal, misalnya laporan surat, pembukuan terkait keuangan gereja. Semua hal itu dapat dilakukan melalui pengaturan kebijakan dari pemimpin gereja dan juga jemaat. Gereja yang baik harus memiliki visi pelayanan dan program pelayanan yang sehat. Karena pekerjaan administrasi dan pelayanan yang baik harus melibatkan seluruh jemaat, maka gereja harus mengatur, memimpin dan mengarahkan seluruh jemaat untuk mewujudkan visi dan program gereja yang berpusat kepada Kristus dan tujuannya hanya untuk kemuliaan Allah. Inilah salah satu prinsip gereja reformatoris untuk menjalankan kehendak Tuhan (Matalu, 2017, p. 817).

Visi gereja menjadi aspek yang penting bagi eksistensi gereja dalam menjalankan mandat Injil. Visi memiliki kekuatan karena kepemimpinan yang efektif dapat dilihat dari visinya. Visi adalah gambar masa depan yang menghasilkan suatu semangat. Gereja yang reformatoris melihat visi dalam pelayanan sebagai suatu masa depan yang baik karena diberikan pemahaman rohani oleh Tuhan kepada pelayan-pelayan-Nya yang terpilih berdasarkan pengertian akurat yang berdasarkan dari Allah sendiri. Pemimpin atau pelayan gereja perlu untuk memperhatikan tentang pengembangan kepemimpinan yang berhati gembala, atau biasa dikenal dengan istilah kepemimpinan hamba (servant leadership). Kepemimpinan ini sangat bernilai karena bersumber dari Yesus sendiri melalui hidup serta pengajaran-Nya. Gereja yang reformatoris dalam aspek mengorganisir dan memimpin memiliki dasar kebaikan, ketulusan hati, relasi, kecakapan dan kesetiaan dalam kebenaran. Prinsip-prinsip ini bersifat kekal, namun 
memang dalam penerapannya membutuhkan waktu serta kerja keras khususnya dalam konteks masyarakat di era sekarang ini (Ronda, 2015, p. 16).

Mengorganisir serta memimpin suatu institusi rohani bukanlah hal yang mudah bagi gereja. Oleh karena itu, gereja yang reformatoris dalam seluruh aktifitas pelayanannya dipimpin oleh Roh Kudus. Para pemimpin gereja harus tunduk untuk dipimpin oleh Roh Kudus, bersandar kepada-Nya, menaati perintah-Nya, dikarenakan Roh Kuduslah yang dikaruniakan oleh Allah kepada semua orang yang taat kepada Dia (Kis. 5:32) (Sihite, 2013, p. 72).

\section{Gereja yang Melayankan Sakramen}

Istilah sakramen berasal dari istilah latin sacramentum yang berarti "sesuatu yang dikuduskan" dan kemudian digunakan sebagai rujukan pada serangkaian tata upacara keagamaan khususnya berkaitan dengan rohaniwan gereja yang mempunyai kualitas spiritual untuk dapat menyalurkan anugerah dari Tuhan (McGrath, 2018, p. 206). Sakramen dipegang sebagai suatu tanda persekutuan tubuh Kristus dan sebagai institusi dari Allah. Dalam sistem presbiterian misalnya, mereka yang sudah ditahbis untuk jabatan yang memangku wewenang melayankan sakramen adalah pastor (pendeta) dan presbiter (majelis/penatua). Melayankan sakramen juga adalah tugas yang bersifat keimaman di dalam gereja, dan harus dibedakan dengan tugas kenabian. Sakramen penting bagi kesejahteraan orang beriman. Sakramen merupakan salah satu pokok dari banyak pertolongan atau bantuan yang penting yang Roh Allah gunakan bagi umat-Nya dalam kelemahan mereka (Hall \& Lillback, 2009, p. 425).

Dalam kaitan dengan natur Allah, Calvin melihat bahwa sakramen tersebut dapat memberikan suatu penghayatan akan kebaikan Allah untuk menyelamatkan umat pilihan-Nya. Dalam kaitan dengan Hukum Taurat misalnya, Calvin menjelaskan bahwa pentingnya untuk mengerti sakramen seperti yang telah Allah sendiri ajarkan dalam Firman-Nya. Dalam kaitan dengan kekuasaan gereja ia menegaskan bahwa sakramen-sakramen jangan ditambahkan atau ditafsirkan ulang oleh gereja. Identitas gereja dapat dilihat dengan adanya sakramen. Tanpa sakramen identitas Kekristenan yang adalah gereja perlu untuk dipertanyakan. Dapat dikatakan lebih lanjut bahwa Firman Allah yang dikhotbahkan dan didengarkan harus beriringan dengan sakramen yang dilaksanakan. Ini semua berasal dari ketetapan Kristus. Dengan demikian kehadiran alat-alat anugerah atau sakramen sebagai sebuah tanda gereja merupakan hal yang sangat penting, disamping kualitas iman dari setiap anggota gereja (McGrath, 2018, p. 235-236).

Sakramen itu sendiri adalah alat anugerah yang dipakai oleh Tuhan untuk meneguhkan setiap orang percaya. Secara historis, sakramen telah digunakan oleh jemaat sejak abad pertama atau abad mulamula. Pada waktu itu sekumpulan orang diperbolehkan hadir serta turut ambil bagian dalam proses Perjamuan Kudus dan dilayani pada waktu Pembaptisan Kudus. Istilah Sakramen atau misterion berarti ada suatu hal yang tersembunyi yang rahasia namun dikuduskan. Soedarmo menyatakan, "Sakramen jumlahnya terdiri atas dua bagian yakni Perjamuan Kudus dan Baptisan Kudus, serta ditentukan oleh Tuhan sendiri (Mat. 28:19; 26:26; 1 Kor.11:23-26)" (2011, p. 235). Perlu diperhatikan juga bahwa sakramen baik baptisan maupun perjamuan kudus merupakan misteri atau rahasia yang diperintahkan oleh Tuhan Yesus. Gereja pada perkembangannya kemudian merumuskan suatu dogma atau sebagai dasar iman Kristen yang dilaksanakan serta dipegang sebagai suatu faith legacy hingga sekarang ini. Gereja-gereja reformasi memahami bahwa sakramen merupakan simbol atau tanda untuk setiap orang percaya dalam persekutuan iman mereka dengan Kristus Yesus (Naat, 2020, p.13). 
Perlu diperhatikan bahwa syarat untuk menerima anugerah yang ditandai dengan sakramen itu adalah kepercayaan. Bagi orang yang tidak percaya, sakramen itu tidak berguna dan tidak mendapatkan anugerah baginya, sebab sakramen itu meneguhkan iman yang telah ada. Tetapi perlu diingat juga bahwa pandangan reformatoris mengajarkan bahwa sakramen tidak mutlak perlu untuk keselamatan, tetapi menjadi kewajiban karena diperintahkan oleh Tuhan. Pengabaian yang disengaja atas sakramen ini akan menghasilkan kemiskinan rohani dan mempunyai kecenderungan destruktif, sama halnya ketidaktaatan yang disengaja terhadap Tuhan.

\section{Gereja yang Melaksanakan Disiplin Gereja}

Disiplin gerejawi adalah salah satu tugas gereja yang tidak boleh diabaikan. Jikalau diketahui atau ditemukan dalam gereja adanya anggota jemaat yang melawan Injil dengan sengaja melalui tindakan yang tidak mencerminkan moralitas kristiani sesuai dengan prinsip-prinsip Alkitab, maka gereja tersebut melalui pimpinan gereja atau majelis harus berani melaksanakan disiplin gerejawi. Tanpa pendisiplinan, gereja tidak dapat bersaksi bagi Tuhan (Tong, 1992, p. 44). Tujuan dari disiplin gereja adalah membangkitkan rasa hormat yang dalam kepada Tuhan dan kekudusan-Nya, sehingga orangorang percaya ingat bahwa mereka harus senantiasa hidup dengan tertib, penuh hormat, dan kudus (Matalu, 2017, p. 819).

Berkhof membagi tujuan disiplin gereja menjadi dua. Tujuan pertama yakni berusaha untuk melaksanakan hukum Kristus berkenaan dengan penerimaan dan penolakan atas anggota. Tujuan kedua adalah untuk memberikan pendidikan secara spiritual kepada anggota gereja dengan cara memastikan ketaatan mereka atas hukum Kristus. Kedua tujuan ini merupakan instrumen agar dapat mencapai tujuan yang lebih tinggi lagi yakni menjaga kesucian gereja milik Yesus Kristus (Berkhof, 2015, p.91). Gereja memegang hak untuk melaksanakan disiplin hanya melalui pemberitaan Firman yaitu dengan peringatan dan himbauan yang ditujukan kepada anggota gereja secara keseluruhan.

Calvin berpendapat bahwa seluruh kuasa gereja untuk menjalankan disiplin menyangkut disiplin di bidang kesusilaan. Ada tiga tujuan bagi Calvin juga yang hendak dicapai gereja bila melakukan teguran atau melaksanakan disiplin gereja. Pertama, agar setiap umat Tuhan yang telah jatuh dalam kehidupan yang tidak baik, memalukan serta keji sebaiknya tidak digolongkan ke dalam kehidupan Kristen. Merupakan suatu penghinaan terhadap Allah apabila orang bejat serta jahat ada di dalam gereja-Nya. Di sini juga diingatkan mengenai sakramen Perjamuan Tuhan, jangan sampai dicermarkan karena dilayankan oleh orang-orang sembarangan. Tujuan kedua ialah supaya orang-orang yang baik tidak dirusak karena terus-menerus bergaul dengan orang-orang yang jahat, sebagaimana biasanya terjadi. Tujuan ketiga ialah supaya mereka sendiri, karena malu mulai menyesali kejahatan mereka. Bagi mereka pun ada gunanya bila kejahatan mereka mendapat hukuman, supaya mereka terbangun oleh rasa pedihnya cambukan-cambukan Kalau dibiarkan saja, mereka akan nekat (Calvin, 2015, p.268269).

Gereja mempunyai tanggung jawab untuk tidak membiarkan anggotanya menjadi penghalang orang lain untuk percaya. Karena itu gereja harus mempunyai disiplin supaya orang jahat di dalam gereja tidak terus berkembang. Jikalau dilihat di antara mereka ada persoalan maka gereja mempunyai tanggung jawab dan hak untuk menasihiati. Tanggung jawab ini harus dipikul oleh hamba Tuhan, tua-tua dan majelis (Soo, 2002, p. 3). Gereja harus menjalankan kewajibannya dan memanggil orang yang berdosa dan menghukumnya sesuai dengan pelanggarannya. Jikalau dosanya ringan, tidak harus disikapi dengan 
begitu keras, peringatan cukup dengan katakata, bahkan hendaknya secara lembut penuh kebapaan. Sehingga tidak menimbulkan rasa dendam atau membingungkan, tetapi menyadarkan kembali kembali, agar teguran itu lebih menyenangkan daripada menyedihkan hati. Dalam Matius 18:15-17, Yesus memberikan wejangan mengenai sikap atau tindakan seseorang jika ada sesamanya yang melakukan perbuatan dosa. Pertama, adalah menegurnya secara empat mata. Jika orang tersebut menolak untuk bertobat, maka harus menegurnya di depan banyak orang saksi. Apabila orang tersebut tetap tidak mau sadar untuk kemudian bertobat, maka diumumkan permasalahan itu kepada jemaat. Jikalau tetap tidak mau mendengarkan jemaat, maka dia akan dikenakan apa yang disebut dengan siasat gerejawi. Instruksi yang diberikan Yesus merupakan hal yang sangat penting terkait disiplin gereja. Dosa yang dibiarkan dan tidak dianggap serius pasti lama-kelamaan akan membawa dampak yang buruk terhadap kehidupan bergereja (Tumanan, 2017, p. 32).

Adapun pelaksanaan disiplin gereja, jika seorang atau lebih anggota jemaat telah melakukan kejahatan moral yang merugikan integritas gereja Kristus, maka disiplin yang dikenakan mencakup empat hal: Pertama, teguran secara empat mata yang dilakukan oleh pendeta (band. Mat. 18:15). Kedua, teguran dengan membawa saksi-saksi yang dilakukan oleh pendeta dan penatua (Mat.18:16). Ketiga, sampaikan perkaranya kepada jemaat (Mat. 18:17a) dan dengan demikian ia diberhentikan dari pelayanan dan keikutsertaannya dalam perjamuan kudus. Keempat, memandangnya sebagai orang yang tidak mengenal Allah (Mat. 18:17b) atau dikucilkan dari gereja (Matalu, 2017, p.821).

Tanggung jawab setiap orang percaya dimulai dengan kesadaran bahwa diri sendiri pernah berbuat dosa dan merugikan dirinya sendiri. Ini penting untuk dijadikan suatu bahan perenungan bagi pelaksanaan disiplin gerejawi. Jadi, tidak hanya pada aspek yang satu bersalah terhadap yang lain, melainkan yang satu bersalah terhadap dirinya sendiri. Yesus mengajarkan proses pelaksanaan disiplin gerejawi dengan pola seperti ini yang kemudian didelegasikan kepada para murid-Nya, kemudian gereja mula-mula serta diteruskan oleh gereja reformasi sampai sekarang ini (Tumanan, 2017, p. 38).

\section{Gereja Reformatoris Masa Kini}

Di dunia yang semakin berkembang ini, dalam aspek ilmu pengetahuan dan teknologi, ekklesiologi tidak hanya berbicara mengenai urusan internal gereja saja, tetapi juga menjadikan seluruh realitas kehidupan yang ada, baik dari masa lalu, masa kini serta masa depan sebagai bahan kajian dan perenungan teologisnya. Jadi gereja dalam konteks masa kini juga adalah upaya dalam hal memahami dan menjabarkan isi dari misi Allah di dalam Kristus. Ini bertujuan untuk pembentukan identitas, wujud, kehadiran dan karya gereja di dunia dalam setiap bidang kehidupan, baik itu sosial, ekonomi, politik, pendidikan dan lain sebagainya. Gereja reformatoris dalam konteks masa kini harus tampil dengan prinsip-prinsip yang alkitabiah yang membawa manusia atau umat Tuhan kepada keselamatan dalam Kristus. Gereja juga harus terus menerus membarui pola keberadaannya dalam dunia. Dengan terus membarui diri gereja juga tidak menjadi statis melainkan dinamis dan progresif dalam pemberitaan tentang Kerajaan Allah. Dengan kata lain, gereja berada di dunia sebagai tanda yang semper reformanda dan terus mau bertumbuh.

Gereja yang reformatoris dewasa ini sama seperti semangat para reformator di masa lampau yang mau tunduk pada otoritas Firman Tuhan, adalah gereja yang dipanggil serta dikhususkan untuk mengabarkan dan mengajarkan kebenaran yang hanya berasal dari Allah. Gereja yang adalah orang-orang percaya dipanggil untuk 
berdoa, bersyafaat terkait realitas kehidupan yang ada, sama seperti Kristus yang bersyafaat terlebih dahulu bagi umat ciptaanNya. Komunitas Kristen dipanggil untuk mempersembahkan diri mereka di atas mezbah kurban yang hidup. Permasalahan kekristenan zaman ini bukan pada tidak adanya gereja sebagai tempat atau gedung, fasilitas atau juga uang, melainkan persoalan utama adalah mereka yang mengaku dengan mulut mereka Kristen tidak dengan hati yang sungguh-sungguh mau berserah dan berkorban untuk Kristus. Selain itu, gereja yang reformatoris perlu juga melihat aspek keadilan yang tidak dapat dipisahkan dengan kasih Kristus. Gereja yang terikat dengan kehidupan duniawi adalah gereja yang hanya fokus pada upaya memperkaya diri sendiri, dan tidak menjalankan kasih dan keadilan Kristus. Ini menjadi suatu bahan perenungan dan pemikiran oleh gereja yang reformatoris. Gereja seyogyanya harus menjadi gereja yang terus melayani setiap orang yang kekurangan, baik jasmani maupun rohani, sehingga secara spiritual mereka lebih mengenal Kristus Yesus.

\section{KESIMPULAN}

Dari analisis serta pembahasan me-

\section{DAFTAR RUJUKAN}

Abineno. J. L. Ch. (2015). Garis-gari Besar Hukum Gereja. Jakarta: BPK Gunung Mulia.

(2018). Pokok-pokok Penting dari Iman Kristen. Jakarta: BPK Gunung Mulia.

Bauckham, R. (1996). Teologi Mesianis; Menuju Teologi Mesianis menurut Jurgen Moltmann (terj. Liem Sien Kie). Jakarta: BPK Gunung Mulia.

Berkhof, L. (2017). Teologi Sistematika 5: Doktrin Gereja. Surabaya: Momentum.

Berkhof, H. dan Enklaar, I. (2016). Sejarah Gereja. Jakarta: BPK Gunung Mulia.

Boehlke, R. (2011). Sejarah Perkembangan Pikiran dan Praktek PAK. Jakarta: BPK Gunung Mulia, ngenai teologi gereja yang reformatoris di atas, maka dapat disimpulkan bahwa gereja tidak hanya menaruh perhatian pada diri gereja itu sendiri melainkan harus terus memancarkan pelayanan yang berdasarkan prinsip-prinsip yang alkitabiah demi kemuliaan Allah. Gereja dapat menjadi wadah yang dipercaya oleh Allah untuk memastikan para pelayan-Nya yang dilengkapi karunia-karunia untuk menjaga kemurnian gereja itu. Di dalam gereja reformatoris ada suatu perlengkapan bagi jemaat, yakni sifat edukatif, penggembalaan, pekabaran injil dan prinsip penatalayanan.

Gereja yang reformatoris biblis setidaknya harus memiliki beberapa prinsip yakni, pertama, sifat untuk memberitakan Injil atau penginjilan. Kedua, gereja reformatoris menekankan pengajaran dan khotbah. Ketiga, gereja yang reformatoris menekankan pelaksanaan manajemen serta kepemimpinan gereja yang baik dan benar. Keempat, gereja harus melayankan sakramen sebagai tanda persekutuan dengan tubuh Kristus. Kelima, gereja yang reformatoris harus melaksanakan disiplin gereja sebagai bagian yang penting dalam suatu institusi ilahi.

Calvin, Y. (2015). Institutio: Pengajaran Agama Kristen. Jakarta: BPK Gunung Mulia.

Enns, P. (2016). The Moddy Handbook of Theology 1. Malang: Literatur SAAT.

Grudem, W. (1994). Systematic Theology: an introduction to biblical doctrine. Grand Rapids: InterVarsity.

Hadiwijono, H. (2016) Iman Kristen. Jakarta: BPK Gunung Mulia.

Hall, D. W. \& Lillback, P. A. (Eds.). (2009). Penuntun ke dalam Theologi Insititutes Calvin: Esai-esai dan Analisis. Surabaya: Momentum.

Heuken, A. (1992) Enslikopedi Gereja. Jakarta: Yayasan Cipta Loka Caraka.

Lumintang, S. (2009). Teologia Abu-abu. Malang: Gandum Mas. 
Matalu, M. Y. (2017). Dogmatika Kristen: Perspektif Reformed. Malang: GKKR.

Moleong, L. J. (2002). Metodologi Penelitian Kualitatif. Bandung: Remaja Rosda Karya

(2005). Metode Penulisan

Kualitatif. Bandung: Remaja Rosda Karya.

Mawikere, M. (2019). Ekumenikalisme: Memperjuangkan Keesaan Gereja. Tateli: IAKN Manado Pascasarjana Teologi.

McGrath, A. E. (2018). Sejarah Pemikiran Reformasi. Jakarta: BPK Gunung Mulia.

Naat, D. E. (2020). Tinjauan Teologis Dogmatis tentang Sakramen dalam Pelayanan Gerejawi. Pengarah: Jurnal Teologi Kristen, 2(1), 1-14.

Niftrik, G. C. \& Boland, B. J. (1990). Dogmatika Masa Kini. Jakarta: BPK Gunung Mulia.

Niesel, W. (2006). The Theology of Calvin. London: Lutterworth.

Ronda, D. (2015). Leadership Wisdom: Analogi Hikmat Kepemimpinan. Bandung: Kalam Hidup.

Siburian, T. (2018). Kristologi Ketuhanan Yesus pada Isu Slavery Gaya Baru: Suatu Usaha Kontekstualiasi Injili. Voice of Wesley: Jurnal IImiah Musik dan Agama, 1(2)

Sihite, J. (2013). Berteologi dan Melayani. Kurios: Jurnal Teologi dan Pendidikan Agama Kristen, 1(1), 67-75.

Soedarmo, R. (2011). Ikhtisar Dogmatika. Jakarta: BPK Gunung Mulia.
Soo, C. (2002). Anugerah dan Disiplin Gerejawi. Malang: SAAT.

Stevanus, K. (2018). Mengimplementasikan Pelayanan Yesus Dalam Konteks Misi Masa Kini Menurut Injil Sinoptik. Fidei: Jurnal Teologi Sistematika dan Praktika, 1(2), 284-298.

Sutanto, H. (2012). Homiletik: Prinsip dan Metode Berkhotbah. Malang: Literatur SAAT.

Thiessen, H. C. (2015). Teologi Sistematika. Malang: Gandum Mas.

Tong, S. (1988). Teologi Penginjillan. Jakarta: Lembaga Reformed Injili Indonesia.

(1992). Reformasi dan Teologi Reformed. Jakarta: Lembaga Reformed Injili Indonesia.

Tumanan, Y. L. (2017). Disiplin Gereja Berdasarkan Injil Matius 18:15-17 dan Implementasinya dalam Gereja Masa Kini. Jurnal Jaffray, 15(1), 31-62.

The Canon of Dorts. (2019). Christian Reformed Church. Retrieved from https://www.crcna.org/welcome/beliefs /confessions/canon-dorts

van den End, Th. (2019). 16 Dokumen Dasar Calvinisme. Jakarta: BPK Gunung Mulia.

Verkuyl, J. (1978). Contemporary Missiology: An Introduction. Grand Rapids: Wm. B. Eerdmans.

Wijaya Lo, J. (2018). Pemuridan Intensional: Dalam Gereja Intensional. Tangerang: UPH Press. 